\title{
INFLUENCE OF PHOTOGRAPHY ON STUDENTS' PERCEPTION OF ELECTRONIC TEXT OF POPULAR SCIENCE
}

\author{
INFLUÊNCIA DA FOTOGRAFIA NA PERCEPÇÃO DOS ESTUDANTES SOBREO \\ TEXTO ELETRÔNICO DAS CIÊNCIAS POPULARES
}

\author{
INFLUENCIA DE LA FOTOGRAFÍA EN LA PERCEPCIÓN DE LOS ESTUDIANTES \\ DEL TEXTO DE CIENCIA ELECTRÓNICA POPULAR
}

Natalia Igorevna KHRISTOFOROVA ${ }^{1}$

\begin{abstract}
The present article analyzes the relevance of the combination of the verbal and non-verbal components of popular science text and the role of computer technologies and the global information network Internet in creating texts of this type. The author conducts a study to assess the impact of Internet technologies on the process of creating electronic popular science text in an attempt to determine the most promising technologies used in this process. The author concludes that the most advanced technologies must be used in creating a popular science text. It is noted that the Internet era opens new opportunities for creating popular science texts, however, the most effective way to create popular science texts combines verbal and non-verbal means (primarily photographs) and modern computer technologies. An important aspect of popular science text is a trend towards the reduction in volume, which is achieved through photographs often replacing lengthy descriptions and explanations. Considering the polysemantic nature of photography and the stabilizing function of a text in relation to an image, an approach to the consideration of verbal and visual components in the framework of popular science text is proposed.
\end{abstract}

KEYWORDS: Verbal component. Non-verbal component. Popular scientific text. Photography. Internet space.

RESUMO: O presente artigo analisa a relevância da combinação dos componentes verbal e não-verbal do texto de ciência popular e o papel das tecnologias de computação e da rede global de informação, a Internet, na criação de textos desse tipo. A autora realiza um estudo para avaliar o impacto das tecnologias da Internet no processo de criação de texto eletrônico de ciência popular na tentativa de determinar as tecnologias mais promissoras utilizadas nesse processo. A autora conclui que as tecnologias mais avançadas devem ser usadas na criação de um texto de ciência popular. Observa-se que a era da Internet abre novas oportunidades para a criação de textos de ciência popular, no entanto, a forma mais eficaz de criar textos de ciência popular combina meios verbais e não verbais (principalmente fotografias) e modernas tecnologias de computador. Um aspecto importante do texto de ciência popular é uma tendência à redução do volume, que é alcançada por meio de fotografias que frequentemente substituem longas descrições e explicações. Considerando a natureza polissemântica da fotografia e a função estabilizadora de um texto em relação a

${ }^{1}$ Moscow Aviation Institute, National Research University (MAI), Moscow - Russia. Associate Professor and Candidate of Philological Sciences ORCID: https://orcid.org/0000-0002-0241-9492. E-mail: n khristoforova@mail.ru 
uma imagem, é proposta uma abordagem para a consideração dos componentes verbais e visuais no quadro do texto de ciência popular.

PALAVRAS-CHAVE: Componente verbal. Componente não-verbal. Texto cientifico popular. Fotografia. Espaço na Internet.

RESUMEN: El presente artículo analiza la relevancia de la combinación de los componentes verbales y no verbales del texto de divulgación científica y el papel de las tecnologías informáticas y la red global de información Internet en la creación de textos de este tipo. El autor realiza un estudio para evaluar el impacto de las tecnologías de Internet en el proceso de creación de textos de divulgación científica en un intento por determinar las tecnologías más prometedoras utilizadas en este proceso. El autor concluye que se deben utilizar las tecnologías más avanzadas para crear un texto de divulgación científica. Se observa que la era de Internet abre nuevas oportunidades para la creación de textos de divulgación científica, sin embargo, la forma más efectiva de crear textos de divulgación cientifica combina medios verbales y no verbales (principalmente fotografias) y tecnologías informáticas modernas. Un aspecto importante del texto de divulgación científica es la tendencia a la reducción de volumen que se logra a través de fotografías que a menudo reemplazan largas descripciones y explicaciones. Considerando la naturaleza polisemántica de la fotografía y la función estabilizadora de un texto en relación con una imagen, se propone una aproximación a la consideración de los componentes verbales y visuales en el marco del texto de divulgación científica.

PALABRAS CLAVE: Componente verbal. Componente no verbal. Texto cientifico popular. Fotografia. Espacio de Internet.

\section{Introduction}

An increased interest in scientific information is currently demonstrated by the audience of non-specialists typically aged from 18 to 40 years old. Such an audience requires specialized knowledge to be translated in a "package" adequate to its level - in the form of popular science information. The increased role of visual content in the context of focusing on a "profane" reader and the corresponding popular science style" (SIMAKOVA, 2016, p. 21) often bring popularity to such publications and online publications as "Bild der Wissenschaft" (n.d), “ScienceBlogs" (n.d), "GEO” (n.d), "Spiegel” (n.d), and "Focus" (n.d).

The authors of electronic popular science texts experiment to adapt traditional techniques to creating new forms of presenting scientific knowledge: "when we talk about the Internet versions of traditional media, we primarily mean the adaptation of genres to new media platforms" (DAVLETSHINA, 2017, p. 89). “Today's graduate of a higher education institution is a professional who feels at ease in the information environment" (KAPUSTINA, 2017, p. 118). Modern students and graduates of higher education institutions can be called 
"digital natives" ("the digital society natives" or "digital generation") (KOTRIKADZE, 2017, p. 19) as they are good at navigating the Internet and can easily operate various gadgets. By virtue of the Internet, popular science discourse is enriched with numerous ways of presenting scientific information: it ensures the transformation of traditional forms on the one hand and the creation of new instruments and forms on the other.

The historical period which began in the first years of the new millennium is called the "information era", reflecting the emergence of new opportunities for information exchange and the active use of interactive computer technologies (ICT) in various areas of social life (KOROTAEVA, 2020, p. 942).

The Internet can be confidently called a platform for the formation of media the main characteristics of which include the digital code, interactivity, and multimedia nature (KURBAKOVA et al., 2020; SKRYLNIKOVA et al., 2020; ZHELTUKHINA et al., 2019;). New media differ from the traditional ones in the possibility of experimenting with the form of presenting information and the means of expression. "Digital media make it possible to present information in a synthetic form combining different systems of symbols - verbal, visual, and auditory. Moreover, a user can not only express their reaction to a media product but also generate its content" (PODANEVA, 2017, p. 55).

With modern information competition in creating popular science texts, the author of such a text faces the following objectives: to not only attract the attention of a non-specialist reader in the described area of knowledge and make the perception of new information easier for them but also consolidate this information in their mind. The emergence of the public Internet has become an incentive to change the texts of printed publications to make them more illustrative. "The audience's demand for multimedia creates favorable conditions for creating polycode texts using two or more semiotic systems" (KUDRIAVTSEVA, 2019, p. 27) as "the network space forms new requirements for... texts but opens a wide range of opportunities at the same time" (KIRILIN; SKRIPCHENKO, 2018, p. 440). Meanwhile, "magazine periodicals do not imply information efficiency. They are designed either for thoughtful reading or for viewing high-quality color illustrations" (KHORINA, 2016, p. 2). Digital technologies affect the reader's perception of information. Such possibilities of electronic text as hypertext links and the formation of "clip thinking" called for the formation of new forms of creating printed texts. On the other hand, despite the existence of electronic versions of popular science publications, their paper-based versions are currently more demanded precisely due to the visual specifics. It should also be noted that such magazines 
have glossy covers and use high-quality paper that is pleasant to touch. The examined popular science publications only use high-quality photographs often taken by researchers working on the topic covered in the text.

The study of the relationship between the verbal component and the image relies on the methodological resource of linguistics in which a text that combines these components is viewed as a creolized text, heterogeneous text, isoverbal text, linguo-visual text, video-verbal text, polycode text, a communicate, or a visual text. Researchers note the emergence and development of a new type of thinking in readers associated with it - the so-called "clip thinking" which involves that a text comprising the visual component is perceived better than a verbal analytical text. In this context, photography is viewed as one of the types of information visualization in text.

Taking into account the verbalization photography is subject to in modern popular science texts, as well as the extrapolation of the linguistic methodological apparatus to the phenomenon of text with a non-verbal component in the form of photographs, it appears relevant to identify an approach to examining such texts based on the logic of the graphic plane within the framework of which such characteristics of photographs as their location and size, as well as the possibility of enlarging and coloring them, are significant.

The value of photographs in popular science text lies in the fact that they allow making quite lengthy verbal descriptions that are not informative for a non-specialist reader (similar to a written text in an unknown language or a written text for an illiterate person) more easily perceivable since photographs documentarily depict fragments of external reality which is important to present complex information correctly. "[...] the presence of photographs which can substitute a scientific explanation for an unprepared reader in a text" (BREDIKHIN et al., 2019, p. 143) helps to present information to a reader in a more accessible form. "A photograph helps the reader to linger in a certain moment, comprehend it, reveal the invisible hidden meanings" (KOVALEVA, 2018, p. 70). A photograph is a crucial informational and visual tool in popular science texts. In combination with text, photographs form a unique linguistic unit. The significance of any text increases if it includes photographs related to its topic since the reader is primarily attracted by the visual component which determines how interesting the text itself is going to be to the reader.

A photograph is a universal unit of non-verbal communication presenting an entire paralinguistic system consisting of special elements: plot, composition, color scheme, gestures and facial expressions, and symbols. Due to the fact that a photograph as a form of visual communication can 
physically fixate certain spatio-temporal events, its broad use becomes easily understandable (KHUTYREVA, 2019, p. 70).

Photographs are no less capable of symbolizing than other non-verbal signs: images in them are characterized primarily by concreteness, clarity, and authenticity, although photographs depicting portraits of prominent researchers can symbolize a field of knowledge or science.

Photographs of scientists, heroes of articles, their portraits or photographs at work present a characteristic feature of the illustrative material of modern popular science texts. Such images have an emotional impact on the reader and create a sort of personal connection between the reader and the hero which ultimately helps the overall perception of the text (SLININA, 2016, p. 47).

A photographic image is polysemic in its nature, open to a variety of sometimes diametrically opposed interpretations depending on the recipient's psychological, sociocultural, and other attitudes... the ambiguity of the polysemy of a photograph is eliminated by the accompanying text (GURTOVAIA, 2019, p. 137).

In popular science texts, the close connection between text and photographs contributes to the efficiency and accuracy of the perception of photographic information.

Owing to such qualities as artistry, information content, and expressiveness, photographs can have their separate meaning. However, the authors of popular science texts almost never use this opportunity. Captions to photographs present an additional opportunity to provide explanation and highlight the main idea of the text:

[...] text not only combines in itself the verbal component of an article and the visual component in the form of an illustration but is also supplied with various captions and notes which most certainly have not only an informative but also a certain of pragmatic orientation (LENKOVA, 2017, p. 102).

A photograph without a caption can lose its meaning for a non-specialist reader or contribute to incorrect interpretation of the text content as a whole since this content is structured in the reader's mind around the plots and images depicted in the photograph. Meanwhile, the location of the caption relative to the photograph can vary: under the photograph, above, or beside it. A caption can help to understand the purpose of a photograph in a specific text. It livens up the text, makes it more specific, easy to understand, motivated, and close to the reader. The use of the verbal component of photographs in a text makes it more informative and valuable as the content of a photograph is enhanced by the corresponding verbal text. Since human memory can perceive and assimilate specific and 
illustrative information first, in the process of reading a text, the reader involuntarily connects the meaning of the words making up the text with the photographs contained in it and organizes said meaning around them. A text without photographs gives a non-specialist reader more opportunities for interpretation of its content since a person's attention is typically drawn to the parts of the text the meaning of which is the closest and understandable for them depending on their abilities, interests, erudition, age, sex, nationality, and mental state at the moment of reading. Such a free interpretation of the text is undesirable for a popular science text since it causes a high probability of an interpretation opposite to what the author intended; therefore, photographs with captions present an important element of popular science texts.

As a rule, photographs demonstrate the object of the study. Photographs can be relevant and show the factual reality described in the text or have a conditional nature. An important element of popular science texts is photographs of researchers, their portrait images, photographs taken at the moment of them doing research activities, as well as photographs of the heroes and authors of the text. Such photographs can have an emotional impact and establish contact between the text reader and its hero or the author which ultimately helps the overall perception of the text.

The location of photographs in the text is important for its understanding and the distribution of semantic accents in it. Photographs should be "read" just as carefully as the verbal part of the text. Similar to texts, photographs can be both easy and difficult to understand and comprehend especially when they depict a new device or an unusual phenomenon.

Using such techniques as choosing the location of an object in a photograph, its color scheme, distribution of light and shadow, the direction of the movement of an object, its size, location in space, and depicting it in motion, the author of the text influences the associative links established in the reader's mind and manages the order in which information in the text is perceived and, therefore, promotes its understanding accounting for the presence of certain concepts in the reader's mind in the form of experiences stored in their memory. These concepts are needed for the generalization of visual information. For instance, such concepts include knowledge of the force of gravity of the Earth, the horizontal and vertical orientation, and the cultural traditions of potential readers.

The level of integration of the non-verbal component is currently quite high in both printed and electronic texts; therefore, we can consider a wide array of functions of photography in texts, for instance, the informative, illustrative, and the function of meaning 
allocation. The characteristics of the interaction of the verbal and non-verbal components need clarification in the context of the dynamic digital media space which is changing in the technological regard and, therefore, brings changes to the spheres of production, distribution, storage, and perception of photography. Thus, visualization can be viewed as the main trend in modern media space. This statement is based on quantitative parameters: while the space occupied by non-verbal information (primarily photographs) is growing, the verbal component decreases. Simultaneously, the electronic text is adapting to the format of websites. Specialists state (SVIRIDOVA; TKALICH, 2016) that only about 20-28\% of words on web pages end up being read. Furthermore, it should be noted here that a person "is more inclined to scan their working space rather than read entire web pages on the Internet. It can be concluded from this that text can be a popular type of Internet content but it is not necessarily the most interesting way to convey information" (SVIRIDOVA; TKALICH, 2016, p. 223).

However, an increase in the amount of visual information also reveals a paradoxical effect: to remain functional, the continuously updated flow of non-verbal materials requires verbalization in the form of captions, both short and quite voluminous, without which it is difficult to understand the essence of what is depicted in the photograph and manage the focus of the quickly scanning glance of the reader which replaced the relaxed examination of printed text. Thus, the role of the non-verbal component in the text also gives a rise to the tendency of verbalization. Based on this, we can discuss the concept of a universal author of a popular science text (typically a journalist specializing in science) who can write a text and select non-verbal material for it equally well. It should also be noted that in popular science texts, the photographs are taken by people other than the authors of texts, often by scientists researching the depicted phenomenon or object which is indicated in captions to photographs.

The texts associated with photographs in electronic popular science texts include both the traditional heading, caption (short or an explanation caption), and the main verbal text and the digital components: the caption on the photo (often against a colored background) with the options to enlarge, scroll, open on a separate page, or use a hyperlink.

\section{Methods}

The empirical study was conducted in 2019 at the Department of Foreign Language for Aerospace Specialties of the Institute of Foreign Languages of the Moscow Aviation Institute (IFL MAI). The study was carried out in the course of one semester in the form of a 
full-time survey of students (120 students) in the Russian language, the results of the survey were entered in a table. The study was based on the analysis of the phenomenon of the interaction of the verbal and non-verbal components in electronic versions of journals "Bild der Wissenschaft", “ScienceBlogs", “GEO”, "Spiegel”, and "Focus”.

The students were presented with printed popular scientific texts from said journals in different versions and asked to briefly evaluate these texts by the criteria of 1) attractiveness, 2 ) the degree of understanding, 3) the degree of informativeness (table 1):

Table 1

\begin{tabular}{|l|l|l|l|l|l|}
\hline & $\begin{array}{l}\text { Text without } \\
\text { illustrations }\end{array}$ & $\begin{array}{l}\text { Text with } \\
\text { black and } \\
\text { white } \\
\text { photographs } \\
\text { without } \\
\text { captions }\end{array}$ & $\begin{array}{l}\text { Text with } \\
\text { black and } \\
\text { white } \\
\text { photographs } \\
\text { with captions } \\
\text { color } \\
\text { photographs }\end{array}$ & $\begin{array}{l}\text { Text } \\
\text { color } \\
\text { photographs } \\
\text { with captions }\end{array}$ \\
\hline $\begin{array}{l}\text { Is the text } \\
\text { interesting? }\end{array}$ & & & & & \\
\hline $\begin{array}{l}\text { Is the text easy } \\
\text { to understand? }\end{array}$ & & & & & \\
\hline $\begin{array}{l}\text { What is the } \\
\text { text about? }\end{array}$ & & & & & \\
\hline
\end{tabular}

Source: Prepared by the author

We were faced with the objectives of 1) evaluating the impact of photographs on the emergence of interest in complex technical scientific information and the understanding and assimilation of this information by students unfamiliar with the examined area of knowledge in the course of reading a popular science text; 2) identifying the most promising methods of structuring popular science texts.

\section{Results}

\section{Student survey results}

To achieve the established goals of the study, the following objectives had to be met:

1. The goal of evaluating the impact of photographs on the formation of interest in complex technical scientific information and the understanding and assimilation of said information by students unfamiliar with the examined area of knowledge in the course of reading a popular science text. The survey results demonstrated that all students were reading popular science texts while $85 \%$ of them were reading them as educational texts in foreign language classes and $15 \%$ of the students were reading them primarily for self-education purposes and to keep track of the latest achievements in science and technology. 
2. The goal of identifying the most promising methods of structuring popular science texts. The students were asked to indicate which popular science texts were the most understandable, interesting, and attractive in their opinion (with an evaluation of the advantages of using photographs in this type of text). The survey demonstrated that the use of photographs in popular science texts presents an undoubted advantage for drawing attention to the text, understanding the complex scientific and technical information contained in it, assimilating this information, facilitating its perception, and consolidating it in the reader's mind. Another important point was the ability of photography to replace voluminous and complex explanations, for example, of the structure of a device, the essence of a chemical process, etc. In this case, the volume of the text is reduced but the content remains unchanged which increases the efficiency of working with the text.

\section{Work with various internet sites}

The study demonstrated that the websites used most often included: https://www.wissenschaft.de/ (popular science journal "Image of Science"), https://scienceblogs.de/ (a blog of researchers and journalists specializing in science), https://www.geo.de/ (a popular science journal), https://www.spiegel.de/ (an information and political journal with an extensive "Science" section), https://www.focus.de/ (an information and political journal with an extensive "Science" section). When choosing a website, students were guided by the degree of reliability of the information provided there. The obtained survey results contained the following indicators evident of the highest degree of 1) attractiveness, 2) the degree of understanding, 3) the degree of informativeness of the popular science text with color photographs with captions:

Table 2

\begin{tabular}{|l|l|l|l|l|l|l|}
\hline & $\begin{array}{l}\text { Text without } \\
\text { illustrations }\end{array}$ & $\begin{array}{l}\text { Text with } \\
\text { black and } \\
\text { white } \\
\text { photographs } \\
\text { without } \\
\text { captions }\end{array}$ & $\begin{array}{l}\text { Text with } \\
\text { black and } \\
\text { white } \\
\text { photographs } \\
\text { with captions } \\
10 \%\end{array}$ & $20 \%$ & $\begin{array}{l}\text { Text with } \\
\text { color } \\
\text { photographs }\end{array}$ & $\begin{array}{l}\text { Text } \\
\text { color } \\
\text { photographs } \\
\text { with captions }\end{array}$ \\
\hline $\begin{array}{l}\text { Is the text } \\
\text { interesting? }\end{array}$ & $1 \%$ & $10 \%$ & $23 \%$ & $15 \%$ & $54 \%$ \\
\hline $\begin{array}{l}\text { Is the text easy } \\
\text { to understand? }\end{array}$ & $2 \%$ & $12 \%$ & $25 \%$ & $16 \%$ & $45 \%$ \\
\hline $\begin{array}{l}\text { What is the } \\
\text { text about? }\end{array}$ & $2 \%$ & $10 \%$ & $50 \%$ \\
\hline
\end{tabular}

Source: Prepared by the author 


\section{Conclusion}

The increased interest of researchers in texts with a non-verbal component and the emergence of such terms as "creolized text" (Iu.A. Sorokin, E.F. Tarasov, E.E. Anisimova), "heterogeneous text" (A.G. Sonin, M.A. Ishchuk), "isoverbal text" (A.A. Bernatskaia), "linguo-visual text" (LM Bolshiyanova), "video-verbal text" (O.V. Poimanova), "polycode text" (G.V. Eiger, V.L. Iukht, A.G. Sonin, A.V. Alferov), "communicator" (V.E. Cherniavskaia), and "visual text"(A.A. Kornienko) testifies to the importance of the ongoing events related to the creation and use of computers, the global information network Internet, global changes in the extraction and understanding of information, instant access to various types of information, as well as the development of information technology.

\section{REFERENCES}

WISSENSCHAFT. Bild der Wissenschaft. Available: https://www.wissenschaft.de/. Access: 10 jul. 2020.

BREDIKHIN, S. N.; SEREBRIAKOVA, S. V.; LIKHOVID, A. A. Sposoby kompressii kognitivnoi informatsii $\mathrm{v}$ nauchno-populiarnom tekste [Ways of cognitive information compression in popular scientific text]. Current issues in philology and pedagogical linguistics, v. 3, n. 71, p. 139-145, 2019.

DAVLETSHINA, S. R. "Novye media" i tendentsii razvitiia multimediinykh zhanrov ["New media" and trends in the development of multimedia genres]. Lingvistika I mezhkulturnaia kommunikatsiia, v. 2, n. 25, p. 86-91, 2017.

FOCUS. Available: https://www.focus.de/. Access: 10 jul. 2020.

GEO. Available in: https://www.geo.de/. Access: 10 jul. 2020.

GURTOVAIA, Y. A. Dialektika verbalnogo i vizualnogo v sovremennoi fotozhurnalistike [Dialectics of verbal and visual in modern photojournalism]. Proceedings of BSTU, v. 4, n. 2, p. 134-138, 2019.

KAPUSTINA, D. M. Problema adaptatsii cheloveka $v$ informatsionnom prostranstve [The problem of human adaptation in the information space]. Filosofskoe obrazovanie, v. 1, n. 35, p. 117-121, 2017.

KHORINA, E. O. Dizain nauchno-populiarnykh izdanii v vospriiatii auditorii (na primere zhurnalov "Vokrug sveta" i "National Geographic") [Design of popular scientific magazines in readers perception: a study of magazines "Vokrug sveta" and "National geographic"]. Ogarev-online, v. 12, p. 1-8, 2016. Available in: http://journal.mrsu.ru/arts/dizajn-nauchnopopulyarnyx-izdanij-v-vospriyatii-auditorii-na-primere-zhurnalov-vokrug-sveta-i-nationalgeographic. Access: 10 jul. 2020. 
KHUTYREVA, A. K. Sposoby manipuliatsii v fotozhurnalistike: prichiny poiavleniia $\mathrm{i}$ eticheskii vopros [Manipulation methods in photojournalism: the reasons for their emergence and the ethical question]. Mediasreda, v. 15, p. 67-71, 2019.

KIRILIN, K. A.; SKRIPCHENKO, M. M. Formy i metody populiarizatsii nauki v rossiiskikh SMI [Forms and methods of popularization of science in russian media]. Mir nauki, kultury, obrazovaniia, v. 4, n. 71, p. 439-441, 2018.

KOROTAEVA, I. E. Interactive Computer Technologies in the Educational Process. International Journal of Advanced Trends in Computer Science and Engineering, v. 9, n. 2, p. 942-950, 2020.

KOTRIKADZE, E. V. O priemushchestvakh ispolzovaniia multimediinykh tekhnologii pri obuchenii inostrannomu iazyku studentov neiazykovykh VUZov [On the advantages of using multimedia technologies in teaching a foreign language to students of non-linguistic universities]. Mir nauki, v. 5, n. 5, p. 17-24, 2017.

KOVALEVA, L. A. Rol zhanra "fotoreportazh" v novoi mediakommunikatsionnoi srede [The role of the "photo report" genre in the new media communication environment]. Sign:

problematic field of media education, v. 3, n. 29, p. 68-72, 2018.

KUDRIAVTSEVA, V. K. Transformatsiia polikodovogo teksta na obloshkakh zhurnala "Tekhnika - molodezhi": istoriko-stilistisheskii aspect [Transformation of polycode text on the covers of the "Tekhnika - molodezhi" magazine: the historical and stylistic aspects]. Mediasreda, v. 16, p. 26-30, 2019.

KURBAKOVA, S. N.; et al. Information technologies in education: application of stream technologies. Revista Inclusiones, v. 7, n. esp., p. 264-278, 2020.

LENKOVA, T. A. Rol podpisi v kreolizovannom publitsisticheskom tekste [The role of photo captions in a creolized media text]. Vestnik Severnogo (Arkticheskogo) federalnogo universiteta, v. 1, p. 102-107, 2017.

PODANEVA, E. S. Nauchnaia populiarizatsiia v internete: eksperimenty s novymi formatami (opyt sozdaniia video proektov o nauke) [Scientific popularization on the Internet: experiments with new formats (experience of creating video projects about science)]. Zhurnalistskii ezhegodnik, v. 6, p. 54-58, 2017.

SCIENCEBLOGS. Available: https://scienceblogs.de/. Access: 10 jul. 2020.

SIMAKOVA, S. I. Vizualnyi kontent na stranitsakh zhurnala "Vokrug sveta" kak sredstvo transliatsii nauchno-populiarnoi informatsii [Visual content in the "Vokrug sveta" magazine as a means of translating popular science information]. Sign: problematic field of media education, v. 4, n. 21, p. 21-29, 2016.

SKRYLNIKOVA, O. A. et al. The impact of mobile technology (byod) and the use of authentic video materials on students' learning effectiveness. Revista Inclusiones, v. 7, n. esp., p. 697-709, 2020. 
SLININA, L. I. Strukturno-semantcheskie osobennosti nauchno-populiarnogo teksta v sovremennom nemetskom iazyke [Structural semantic features of the popular science text in the modern German language]. Arkhivarius, v. 2, n. 1-5, p. 45-50, 2016.

SPIEGEL. Available: https://www.spiegel.de/. Access: 10 jul. 2020.

SVIRIDOVA, A. V.; TKALICH, S. K. Sintez tekhnologii multiplikatsii i tsifrovogo foto dlia sozdaniia multimediinogo produkta $\mathrm{v}$ ramkakh tekhnologii storitellinga [Synthesis technology of animation and digital photo to create a multimedia product as part of storytelling techniques]. Simvol nauki, n. 11-3, p. 222-225, 2016.

ZHELTUKHINA, M. R. et al. Media promotion role of economic vocabulary: specific features and functions in presentation and advertisement. Online Journal of Communication and Media Technologies, v. 9, n. 2, e201907, 2019.

\section{How to reference this article}

KHRISTOFOROVA, N. I. Influence of photography on students' perception of electronic text of popular science. Rev. EntreLínguas, Araraquara, v. 7, n. esp. 2, e021025, 2021. e-ISSN: 2447-3529. DOI: https://doi.org/10.29051/el.v7iesp.2.15151

Submitted: 05/01/2021

Required revisions: $26 / 02 / 2021$

Approved: $24 / 03 / 2021$

Published: 01/06/2021 